\title{
Distribution of the Beta-Casein Gene Variants in Three Cattle Breeds Reared in Benin
}

\author{
Camus Mahougnon Adoligbe ${ }^{1}$, Stéphanie Gloria Akpo ${ }^{1}$, Santoze Adido ${ }^{1}$, Marguéritte $\mathrm{M}^{\prime} \mathrm{Po}^{1}$, \\ Ange-Régis Zoclanclounon ${ }^{1}$, Samuel Mantip ${ }^{2}$, Yao Akpo $^{3} \&$ Souaïbou Farougou ${ }^{1}$ \\ 1 Research Unit on Communicable Diseases, Polytechnic School of Abomey-Calavi, University of \\ Abomey-Calavi, Cotonou, Benin \\ ${ }^{2}$ Virology Division, National Veterinary Research Institute, Nigeria \\ ${ }^{3}$ Directorate of Husbrandy, Cotonou, Akpakpa, Benin \\ Correspondence: Camus Mahougnon Adoligbe, Research Unit on Communicable Diseases, Polytechnic School \\ of Abomey-Calavi, University of Abomey-Calavi, 01BP 2009, Cotonou, Benin. E-mail: adolcam83@yahoo.fr
}

Received: November 30, $2021 \quad$ Accepted: January 6, $2022 \quad$ Online Published: January 15, 2022

doi:10.5539/jas.v14n2p86 URL: https://doi.org/10.5539/jas.v14n2p86

\begin{abstract}
The beta-casein gene is one of the most functional genetic candidate that affect milk quality and composition traits. Among its variants, the A1/A2 are the most common. Therefore, the aim of this study was to identify the distribution of the Beta-casein gene variants (A1/A2) in three different cattle breeds in order to determine which of the breed produce a better milk for consumers' health.

152 blood samples which comprises 72 (Muturu), 40 (Azawak) and 40 Girolando were used to carry out this study. Genomic DNA was extracted from the blood samples and each variant was subsequently amplified from the extracted DNA samples using an Allele-Specific PCR technique and then confirmed by running the PCR products on $1 \%$ agarose gel.

The result showed that there were three genotypes (A1A1, A2A1 and A2A2) in the three breeds. The average percentage genotypic frequencies obtained from this study were $42.76 \%, 31.58 \%$ and $25.66 \%$ respectively for $\mathrm{A} 1 \mathrm{~A} 1, \mathrm{~A} 1 \mathrm{~A} 2$ and $\mathrm{A} 2 \mathrm{~A} 2$ genotypes while the percentage allelic frequencies were $58 \%$ and $42 \%$ respectively for A1 and A2 allele. The genetic parameters of Azawak breed were higher than that of the other breeds, what implies that there was a higher polymorphism and genetic diversity in the Azawak breed in the beta-casein gene compare to the other breeds.

The A2 beta-casein variant in milk has been found to be desirable for milk consumer's health and nutrition. This study therefore showed that the Azawak breed provides a good potential for increasing this favorable allele through appropriate breeding techniques of cattle.
\end{abstract}

Keywords: livestock, marker-assisted selection, milk, quality, one health, therapeutic value

\section{Introduction}

Cattle production is an important component of the gross domestic product (GDP) of Benin as a country. They provide products such as beef and milk which contribute more than $50 \%$ of the annual gross domestic income of the country (Anihouvi et al., 2019; Toko et al., 2015). Bovine milk is a nutrient-rich liquid food which serves as a source of high-quality protein and minerals such as calcium, magnesium and phosphorus (Hanusová et al., 2010). Due to their nutritional properties, milk proteins are considered as one of the most valuable components of the human diet.

The cow milk protein components such as Alpha-casein, Beta-casein, Kappa-casein, Beta-lactoglobulin and Alpha-lactalbumin are included in the quality-based assessment of many dairy companies as well as in the selection indexes of different breeds of cattle (Volkandari et al., 2017; Franzoi et al., 2019). The beta-casein constitutes up to $45 \%$ of bovine milk total casein and presents 12 genetic variants (A1, A2, A3, B, C, D, E, F, G, H1, H2 and I). However, variants A1 and A2 are the most important and common variants in dairy cattle breeds (Massella et al., 2017). They differ in amino acid position 67 with histidine (CAT) in A1 and 
proline (CCT) in A2 variant. This is as a result of a single nucleotide difference in the sequence of exon VII of bovine beta-casein gene (Raynes et al., 2015).

The beta-casein gene is one of the most functional genetic candidate that affect milk quality and composition traits in cattle. It is primarily involved in the cheese-making process and also during curd firming period (Amalfitano et al., 2019; Čítek et al., 2020; Saha et al., 2020). Recent studies that focused on the A1 and A2 beta-casein polymorphic forms associated the A1 variant with adverse effects on human health (Daniloski et al., 2021; Kaskous, 2020). The studies imply that the proteolytic digestion of the A1 variant normally produced the beta-casomorphin 7 (BCM-7) which is associated with diseases such as type I diabetes mellitus and cardiovascular diseases such as Ischaemic heart disease and it could also be responsible for milk protein intolerance in some individuals. Furthermore, the BCM-7 appears to be implicated in the severe form of certain diseases such as autism, schizophrenia and Sudden Infant Death Syndrome (Parashar \& Saini, 2015; Şahin et al., 2018). However, the consumption of milk with a high proportion of the A2 variant can be associated with some health benefits and can also improve the digestibility of milk in the human body system (Bell et al., 2006). It is therefore suggested that the selection of cattle with only the A2 variant of the beta-casein gene may have a positive impact on human health with little or no negative effect on milk yield and composition from the cattle (Cieślińska et al., 2019).

In Benin, milk and milk by products, particularly the local milk cheese popularly known as "Wagashi Gasire", the milk based local beverage also popularly known as "Degue" and the milk curd are highly appreciated and consumed by the people. However, to the best of our knowledge, there is no research on the genomic analysis of the major bovine milk proteins genes in the country. Therefore, the objective of this study was to determine the frequency of beta-casein gene variants (A1/A2) in some selected local and conventional cattle breeds in Benin. This is in order to generally contribute in the improvement of milk production and milk consumer's nutrition and health.

\section{Material and Methods}

\subsection{Experimental Site and Design}

Blood samples were collected in $10 \mathrm{ml}$ Sodium-EDTA vacutainers from 72 Muturu, 40 Azawak and 40 Girolando cattle (Figure 1). The animals were chosen according to their age and sex what explain the variation in sample size between study sites. Indeed, to minimize sex and age effect, only cows of 3 to 5 years old were selected. The age of the animals was determined using the method of Torel et al. (2003). These animals were reared in similar conditions at Samiondji (Southern Benin), Opkara (Northen Benin) and Kpinnou (Southern Benin) state owned farm respectively. The southern regions of Benin receive two seasons of rainfall from March to July and September to November with an average rain fall of around $1,200 \mathrm{~mm}$. The dry seasons extend from August to September and from December to March (Haggett, 2002). The northern regions of Benin, in general, receive one season of rainfall from May to September. The average temperature from April to June reaches $40{ }^{\circ} \mathrm{C}$, while the average temperature between November and March ranges between 12 and $25^{\circ} \mathrm{C}$ (Haggett, 2002).

The blood samples were collected from the jugular vein upon the approval of the Directorate of Husbandry. The samples were properly labeled and immediately transported to the Research Unit of Communicable Diseases of the University of Abomey-Calavi and stored in $-20^{\circ} \mathrm{C}$ freezer before analysis. During sampling, the animals were handled humanely to avoid pain and discomfort. Genomic DNA was extracted from the whole blood according to the manufacturer's instructions by using the DNA extraction kit (ZymoBead ${ }^{\mathrm{TM}}$ Genomic DNA Kit, D3004, United States) developed by Zymo research group. The extracted DNA was identified by electrophoresis on $1 \%$ agarose gel. The purity and concentration of the DNA were also carried out with Qubit ${ }^{\mathrm{TM}} 4$ fluorometer (Thermo fisher Scientific, Singapore) according to the manufacturer's instructions. 

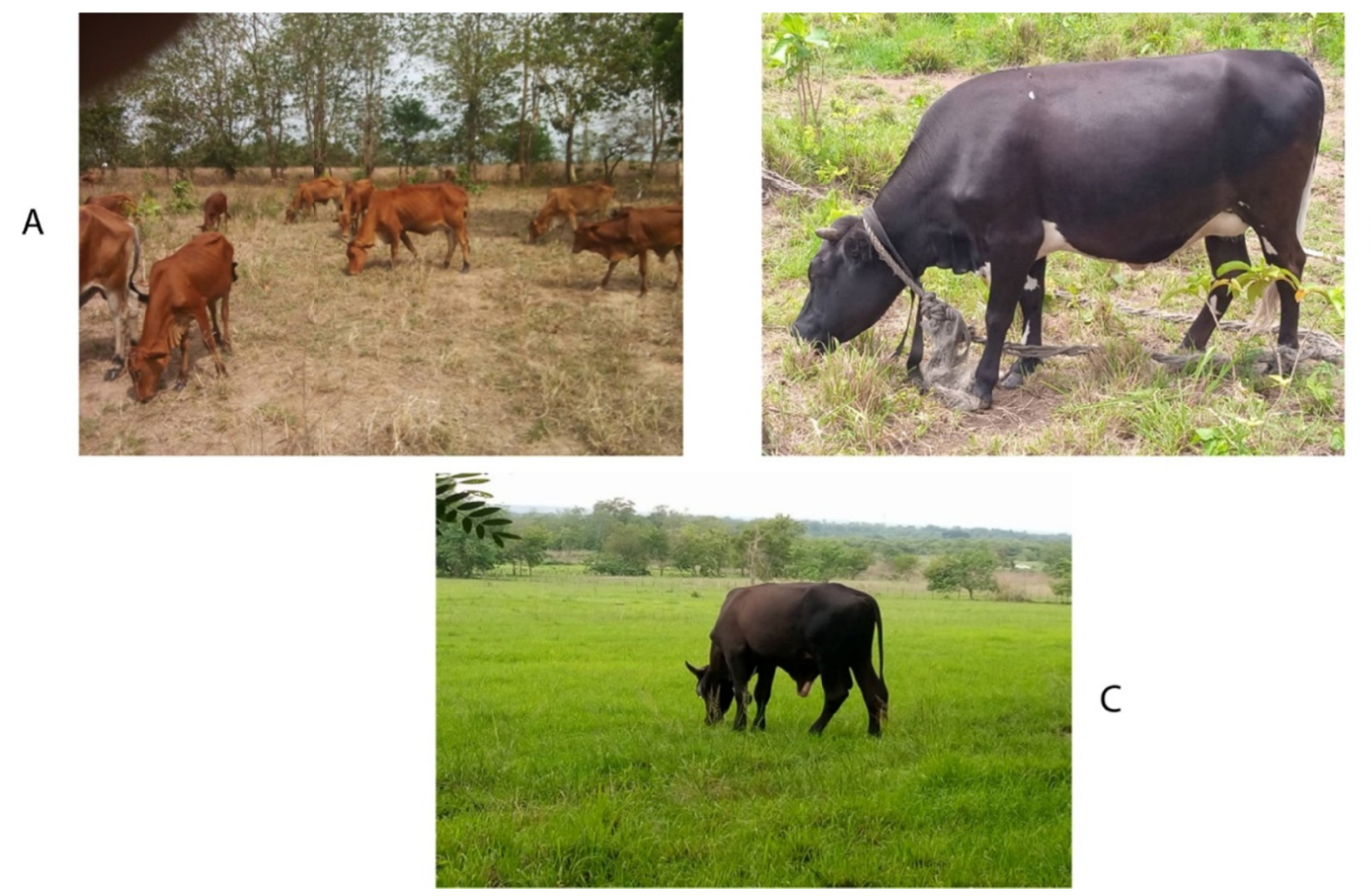

Figure 1. Cattle breeds $(\mathrm{A}=$ Azawak; $\mathrm{B}=$ Muturu; $\mathrm{C}=$ Girolando $)$

\subsection{Genotyping}

An allele specific-polymerase chain reaction (AS-PCR) was performed to amplify a fragment of $854 \mathrm{bp}$ including part of intron 6 and exon 7 of the Beta casein gene. Allele-specific PCR is a reliable less expensive technology used worldwide in SNP genotyping. It has already been used to detect mutation points in DNAs and in DNA-based diagnostic techniques including the diagnostic of genetic and infectious diseases (Ugozzoli \& Wallace, 1999; Soleimani et al., 2003; Gaudet et al., 2009; Lin et al., 2020; Malakootikhah et al., 2021). Primer pair 5'-GCC CAG ATG AGA GAA GTG AGG-3'/5'-GAT GTT TTG TGG GAG GCT GTT AT-3' and primer pair 5'-GAT GTT TTG TGG GAG GCT GTT AG -3'/5'-GCC CAG ATG AGA GAA GTG AGG-3' were synthesize to amplify variant A1 and variant A2 of the CSN2 gene respectively. These primers were tested by previous authors and their robustness and discriminant power was proved (Keating et al., 2008; Rahimi et al., 2015). The PCR reactions were carried out in a $25 \mu \mathrm{l}$ volume containing $12.5 \mu \mathrm{l}$ of PCR Master Mix (One Taq quick load Bio lab, Belgium), 4.5 pmol of each primer, and $40 \mathrm{ng}$ of template DNA. The PCR conditions were as follows: an initial denaturation step at $94{ }^{\circ} \mathrm{C}$ for $5 \mathrm{~min}, 30$ cycles of $94{ }^{\circ} \mathrm{C}$ for $1 \mathrm{~min}, 62.1^{\circ} \mathrm{C}$ for $1 \mathrm{~min}, 72{ }^{\circ} \mathrm{C}$ for $1 \mathrm{~min}$, and a final extension step of $72^{\circ} \mathrm{C}$ for $10 \mathrm{~min}$. All the PCR reactions in this study were performed in the $\mathrm{VWR}^{\circledR}$ UNO Thermal cycler.

Amplification was confirmed by running the PCR products on 1\% agarose gel and visualized with a Gel Documentation System (Ultra-Violet Products Ltd., United Kingdom). The PCR reaction was performed in simplex and any time a particular allele is not amplified from an individual DNA; the whole process was repeated 2 more times to make sure the obtained result characterizes the individual.

\subsection{Statistical Analysis}

The genetic variation parameters which includes genotypic frequencies, allelic frequencies, Hardy-Weinberg equilibrium (HWE), gene homozygosity (Ho), gene heterozygosity $(\mathrm{He})$ and effective allele numbers $(\mathrm{Ne})$ were estimated using the Mathematical model of (Nei \& Roychoudhury, 1974) and (Nei \& Li, 1979). The samples size used to carry out this study was considerably up to the expected standard as described by Willing et al. (2012) for the estimation of the genetic diversity of the studied breeds of cattle.

\section{Results}

The PCR products of the Beta-casein gene were obtained using a specific set of primers with $854 \mathrm{bp}$ fragments indicating the presence of either A1 or A2 variants according to the primer fragments used in the PCR mix 
reaction (Figure 2). Three different genotypic bands were shown on the agarose gel, namely A1A1 homozygote, $\mathrm{A} 1 \mathrm{~A} 2$ heterozygote and A2A2 homozygote bands. The A1A2 heterozygote candidates were candidates whose genomic DNA exhibited the same $854 \mathrm{bp}$ fragment from each of the two pairs of primers used. The genetic diversity of the locus was then calculated as indicated in (Tables 1 and 2). The average percentage genotypic frequencies obtained from this study were $42.76 \%, 31.58 \%$ and $25.66 \%$ respectively for A1A1, A1A2 and A2A2 genotypes while the percentage allelic frequencies were $58 \%$ and $42 \%$ for A1 and A2 allele respectively. The comparison within breeds revealed that the percentage genotypic frequencies obtained for Muturu breed were $42 \%, 39 \%$ and $19 \%$ for the $\mathrm{A} 1 \mathrm{~A} 1, \mathrm{~A} 1 \mathrm{~A} 2$ and $\mathrm{A} 2 \mathrm{~A} 2$ genotype respectively, while the percentage allelic frequencies were $61 \%$ and $39 \%$ for A1 and A2 allele respectively. Concerning the Azawak breed, the A1A1, $\mathrm{A} 1 \mathrm{~A} 2$ and $\mathrm{A} 2 \mathrm{~A} 2$ genotypes frequencies were $25 \%, 30 \%$ and $45 \%$ respectively, while the percentage allelic frequencies were $40 \%$ and $60 \%$ for the $\mathrm{A} 1$ and $\mathrm{A} 2$ allele respectively. Percentage genotypic frequencies obtained for Girolando breed were $63 \%, 20 \%$ and $17 \%$ for the A1A1, A1A2 and A2A2 genotype respectively, while the percentage allelic frequencies were $72 \%$ and $28 \%$ for A1 and A2 allele respectively (Table1). He, Ne of Azawak breed were the highest (Table 2), this implies that the polymorphism and genetic diversity of the Azawak breed were higher compare with the Muturu and Girolando breeds. The $\chi^{2}$ test showed that genotype distribution in all the breeds agreed with Hardy-Weinberg equilibrium $(\mathrm{P}>0.05)$.

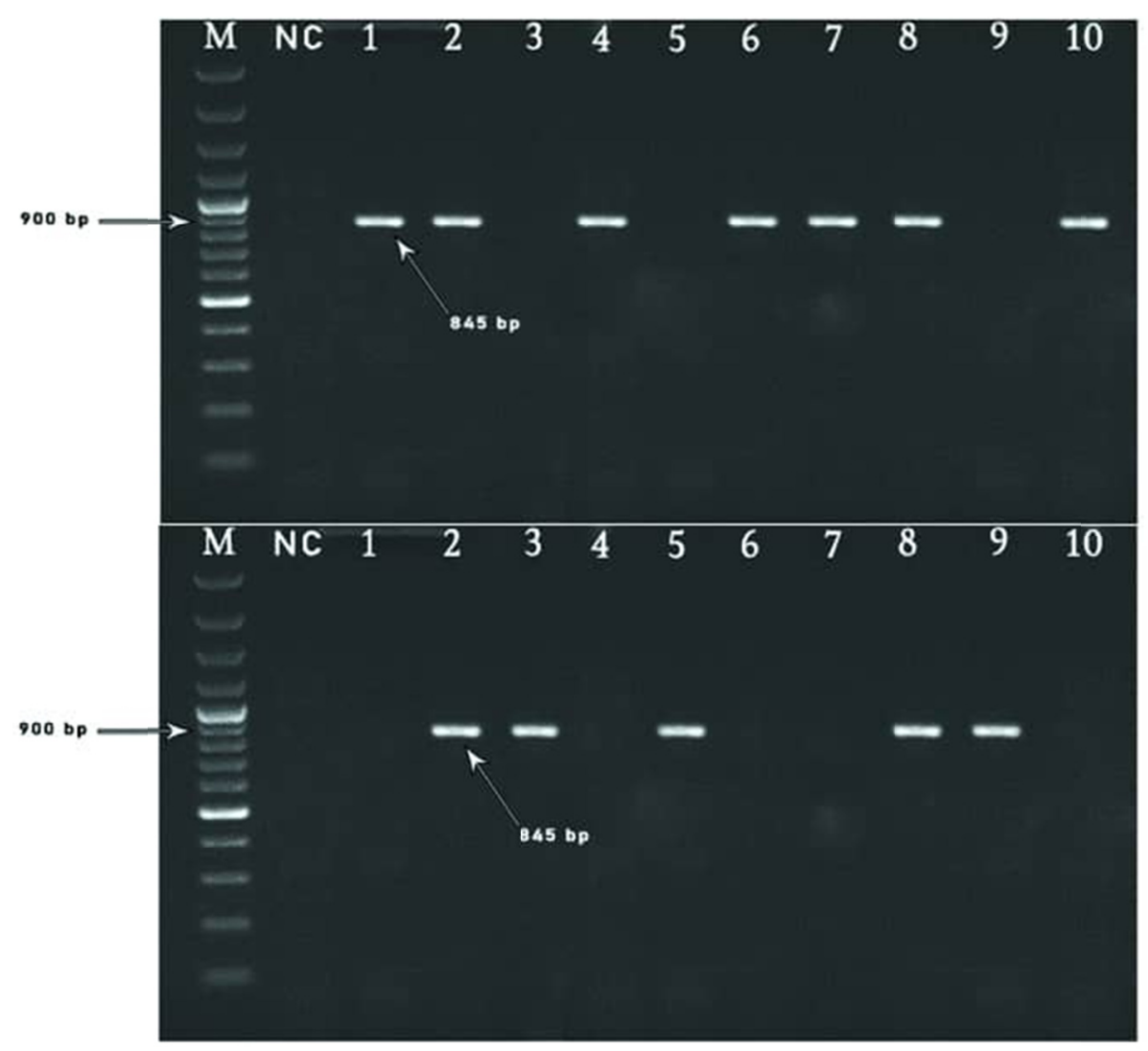

Figure 2. Agarose gel separation showing $854 \mathrm{bp}$ fragment which indicates either the presence of variant A1 or variant $\mathrm{A} 2$ according to the pair of primer used. 1, 4, 6, 7, $10=\mathrm{A} 1 / \mathrm{A} 1$ individuals; 3, 5, $9=\mathrm{A} 2 / \mathrm{A} 2$ individuals; $2,8=\mathrm{A} 1 / \mathrm{A} 2$ individuals

Note. M: Ladder 100kb, NC: Negative control. 
Table 1. Genotype and allele frequencies in the Beta casein gene locus of the targeted breed

\begin{tabular}{|c|c|c|c|c|c|c|}
\hline \multirow{2}{*}{ Breed } & \multirow{2}{*}{ Number of individuals } & \multicolumn{3}{|c|}{ Genotype Frequencies } & \multicolumn{2}{|c|}{ Allele Frequencies } \\
\hline & & A1A1 & $\mathrm{A} 1 \mathrm{~A} 2$ & $\mathrm{~A} 2 \mathrm{~A} 2$ & A1 & A2 \\
\hline Muturu & 72 & $0.42(30)$ & $0.39(28)$ & $0.19(14)$ & 0.61 & 0.39 \\
\hline Azawak & 40 & $0.25(10)$ & $0.30(12)$ & $0.45(18)$ & 0.40 & 0.60 \\
\hline Girolando & 40 & $0.63(25)$ & $0.20(8)$ & $0.17(7)$ & 0.72 & 0.28 \\
\hline Total & 152 & $42.76(65)$ & $31.58(48)$ & $25.66(39)$ & 0.58 & 0.42 \\
\hline
\end{tabular}

Table 2. Population genetic indices in the Beta casein gene locus of the targeted breed

\begin{tabular}{lllll}
\hline Breed & Ho & $\mathrm{He}$ & $\mathrm{Ne}$ & $\chi^{2}$ (HWE) \\
\hline Muturu & 0.53 & 0.47 & 1.90 & 2.38 \\
Azawak & 0.52 & 0.48 & 1.92 & 5.62 \\
Girolando & 0.60 & 0.40 & 1.66 & 9.37 \\
\hline
\end{tabular}

Hardy-Weinberg equilibrium (HWE), gene homozygosity (Ho), gene heterozygosity (He), effective allele numbers $(\mathrm{Ne})$.

\section{Discussion}

The observed dominance of A1 variant of the beta-casein gene in Muturu and Girolando breeds in our study is in agreement with some previous findings. A1 has been found to be the most frequent variant in; Ayrshire (0.432-0.720), Red cattle (0.710), Pinzgau breed (0.5618) and the Black-and-White breed (0.550) (Cieślińska et al., 2019; Kamiński et al., 2007; Miluchová et al., 2014). In contrast, a higher frequency of A2 was observed in Azawak breed as it was the case of Vrindavani crossbred (0.650) and Sahiwal breed (0.940) (Kumar et al., 2019).Similar findings were also observed in Guernsey breed (0.880-0.970), Jersey breed (0.490-0.721), Italian Holstein Friesian breed (0.6065), Simmental breed (0.758), Slavonian-Syrmian Podolian cattle breed (0.673), Istrian cattle breed (0.733), Brown Swiss breed (0.675), Busa cattle breed (0.653) and the Kermanshah cattle breed (0.618) (Ivanković et al., 2021; Kamiński et al., 2007; Rahimi et al., 2015; Sebastiani et al., 2020).

Based on literature, most of the studies carried out on the A1/A2 polymorphism of the beta-casein gene on exotic western cattle breeds have shown that the allelic frequency of the A2 variant is significantly higher than that of the A1 variant. This could be as a result of the selection method which favours one genetic variant in these countries over the years. Indeed, in the past three decades, casein have drawn a special interest and attention to scientists and dairy consumers due to the potential relationship between beta-casein genotype of the bovine milk protein and the health of cow milk consumers (Daniloski et al., 2021; Joshi et al., 2021; Park \& Haenlein, 2021). Therefore, it has been reported that the beta-casomorphin-7 (BCM-7) generated from A1 variant bovine milk causes human health hazards. This is because it has been shown to have potentials in influencing a variety of opioid receptors in the endocrine, nervous and immune systems which result in gradual adverse development of some depilating human ailments such as diabetes, heart diseases, schizophrenia and autism (Daniloski et al., 2021). On the other hand, no relationship in previous studies has been found to link the presence of the A2 variant in the cow milk that results to any form of protein allergy or health problems (Priyadarshini et al., 2018). Recently, Cuevas et al. (2021) reported that the A2 variant has the possibility of extending the shelf-life of milk and other dairy products and it also has a high anti-oxidant activity than the A1 variant. Moreover, some authors suggest that the A2 variant could be a useful marker for the improvement of milk production traits, particularly for milk yield. Therefore, cow milk containing the $\mathrm{A} 2$ gene variant has been recommended to be commercially marketed in some Western countries for quite a long period of time now.

To the best of our knowledge, we have come to the realization that only quite a couple of studies to date have been carried out in the characterization of the variability of the beta-casein gene in Africa. However, the overall low frequency of the A2 variant observed in our study may be due to the evidence of an existing genetic variability for milk quantitative trait loci in the targeted breeds. The inter-breed allelic frequencies difference observed in our study is in agreement with the previous findings of Ibeagha-Awemu et al. (2004). Indeed, the authors reported a relatively higher frequency of A2 variant in Bos indicus breeds compare to the Bos Taurus breeds from Cameroon and Nigeria. The Girolando breed involved in our study is dairy cattle breed cross-bred in Brazil by crossing Gyr cattle, a Bos indicus breed with Holstein cow, a Bos taurus breed. They were brought to Benin through a national program aim at improving milk production. In an open grazing condition, they produced an average of 9 liters of milk per day (Dossou et al., 2016). On the other hand, the Muturu cattle which are a Bos taurus breed are found to 
be distributed almost all-over West Africa. They are primarily bred for their ability to live and survive in the harsh tropical climatic environmental condition (Adoligbe et al., 2020). However, they produce low milk quantity of 0.5 liters per day in average in an extensive breeding system. The Azawak breed on the other hand, is a West African Bos indicus dairy cattle that originated from Niger and Mali. The average milk production of this breed is around 3.4 liters per day in an extensive breeding system (Ouédraogo et al., 2021).

From these three studied breeds of cattle, the Azawak breed showed the highest A2 variant frequency and also a higher genetic variability of the casein gene locus. Previous studies conducted on the technological properties of some selected cattle breed milk in Benin has shown the following fresh cheese yield values in a descending order: 28\%, 27.6\%, 24\% and 18.4\% respectively for the Borgou, Muturu, Azawak and Girolando cattle breeds (Kora, 2005; Tougan et al., 2018; Ouédraogo et al., 2021). The same authors also reported that the Azawak cow milk has a high protein content and low-fat content. These results are in line with a previous literature that indicated a negative relation of allele A2 on milk fat content but a positive relation on milk protein content. Although Ristanić et al., (2020) reported a positive relation of allele A2 on both milk protein and milk fat. The highest percentage of A1 variant observed in the Girolando breed in our study could partly be the result of mating of individuals that are closely related genetically. In fact, many of the Girolando cattle from the original herd brought to the country, have died due to their inability to cope with the harsh local tropical environmental climatic condition leaving a small breeding stock from which has originated most of the Girolando cattle of the country.

\section{Conclusion}

Polymorphisms in candidate genes was found to be related to the economically important traits in cattle. The Beta-casein gene has over the years been associated with milk production, milk composition, milk quality, cheese production as well as curd production. This work studied the distribution of Beta-casein gene variants in three cattle breeds reared in Benin. The results obtained indicated that, the A1 variant of the beta-casein gene dominates the A2 variant in the studied cattle breeds except the Azawak breed which showed a greater rate of A2. Therefore, the Azawak breed could be a better candidate to economically increase the production and the competitiveness of small sized dairy farms in Benin. Our results could be the baseline for other up-coming studies that will focus on the development of the quality, quantity and health benefit of cow milk produce in Benin and other neighboring countries where these breeds are reared. However, it is necessary to expand the study database by including other cattle breeds and also by enlarging the samples size. A robust data will therefore be generated and could be used to initiate a breeding program with the aim of lowering the frequency of the A1 variant amongst the selected cattle breeds while minimizing the risk of genetic diversity lost. Moreover, it is important to study the Beta-casein polymorphism in combination with other polymorphic milk proteins, such as Kappa-casein and Beta-lactoglobulin as they all have the tendency to influence the casein micelle structure and the overall milk properties and milk products.

\section{Acknowledgements}

We extend our sincere appreciation to the staff of the state cattle farms for their support and involvement in the data collection process.

\section{References}

Adoligbe, M. C., Amaveda, M. A., Adido, M. S., Djimenou, D., \& Farougou, S. (2020). Muturu cattle breed management in the smallholder farming area of the Ouémé district in the south of Benin: Rearing practices, objectives, and constraints. Tropical Animal Health and Production, 52, 3015-3025. https://doi.org/10.1007/ s11250-020-02320-8

Amalfitano, N., Cipolat-Gotet, C., Cecchinato, A., Malacarne, M., Summer, A., \& Bittante, G. (2019). Milk protein fractions strongly affect the patterns of coagulation, curd firming, and syneresis. Journal of Dairy Science, 02, 2903-2917. https://doi.org/10.3168/jds.2018-15524

Anihouvi, E. L., Salih, H., Anihouvi, V. B., \& Kesenkas, H. (2019). Milk and Dairy Products Production in Benin. Akademik Gıda, 17, 508-516. https://doi.org/10.24323/akademik-gida.667265

Bell, S. J., Grochoski, G. T., \& Clarke, A. J. (2006). Health implications of milk containing $\beta$-casein with the A2 genetic variant. Critical Reviews in Food Science and Nutrition, 46, 93-100. https://doi.org/10.1080/ 10408390591001144

Cieślińska, A., Fiedorowicz, E., Zwierzchowski, G., Kordulewska, N., Jarmolowska, B., \& Kostyra, E. (2019). Genetic polymorphism of $\beta$-Casein gene in Polish Red Cattle-Preliminary study of A1 and A2 frequency in genetic conservation herd. Animals, 9, 377. https://doi.org/10.3390/ani9060377 
Čítek, J., Brzáková, M., Hanusová, L., Hanuš, O., Večerek, L., Samková, E., .. Straková, K. (2020). Technological properties of cow's milk: correlations with milk composition, effect of interactions of genes and other factors. Czech Journal of Animal Science, 65, 13-22. https://doi.org/10.17221/150/2019-CJAS

Cuevas, G. T. A., Angeles, A. A., Merca, F. E., \& Salces, A. J. (2021). $\beta$-casein Variants and Anti-oxidant Profiles of Milk of Siquijor Native Cattle (Bostaurus indicus L.) as Compared to those of Holstein Friesian $\times$ Sahiwal Cattle. Tropical Animal Science Journal, 44, 108-114.https://doi.org/10.5398/tasj.2021.44.1.108

Daniloski, D., Cunha, N. M., McCarthy, N. A., O’Callaghan, T. F., McParland, S., \& Vasiljevic, T. (2021). Health-related outcomes of genetic polymorphism of bovine $\beta$-casein variants: A systematic review of randomised controlled trials. Trends in Food Science \& Technology, 111, 233-248. https://doi.org/ 10.1016/j.tifs.2021.02.073

Dossou, J., Atchouké, G. D., Dabadé, D. S., Azokpota, P., \& Montcho, J. K. (2016). Evaluation Comparative De La Qualite Nutritionnelle Et Sanitaire Du Lait De Differentes Races De Vaches De Quelques Zones D'elevage Du Benin. European Scientific Journal, 12, 141. https://doi.org/10.19044/esj. 2016.v12n3p141

Franzoi, M., Niero, G., Visentin, G., Penasa, M., Cassandro, M., \& De Marchi, M. (2019). Variation of detailed protein composition of cow milk predicted from a large database of mid-infrared spectra. Animals, 9, 176. https://doi.org/10.3390/ani9040176

Gaudet, M., Fara, A.-G., Beritognolo, I., \& Sabatti, M. (2009). Allele-Specific PCR in SNP Genotyping. In A. Komar (Eds.), Single Nucleotide Polymorphisms. Methods in Molecular Biology ${ }^{\mathrm{TM}}$ (Methods and Protocols) (Vol. 578). Humana Press, Totowa, NJ. https://doi.org/10.1007/978-1-60327-411-1_26

Haggett, P. (2002). Encyclopedia of World Geography. Marshall Cavendish.

Hanusová, E., Huba, J., Oravcová, M., Polák, P., \& Vrtková, I. (2010): Genetic variants of beta-casein in Holstein dairy cattle in Slovakia. Slovak Journal of Animal Science, 43, 63-66.

Ibeagha-Awemu, E. M., Jann, O. C., Weimann, C., \& Erhardt, G. (2004). Genetic diversity, introgression and relationships among West/Central African cattle breeds. Genetics Selection Evolution, 36, 1-18. https://doi.org/10.1186/1297-9686-36-6-673

Ivanković, A., Pećina, M., Ramljak, \& Pašić, V. (2021). Genetic polymorphism and effect on milk production of CSN2 gene in conventional and local cattle breeds in Croatia. Mljekarstvo: Časopis za UnaprjelDjenje Proizvodnje i Prerade Mlijeka, 71,3-12. https://doi.org/10.15567/mljekarstvo.2021.0101

Joshi, S. K., Semwal, R., Kumar, A., Chauhan, A., \& Semwal, D. K. (2021). Indian cow and A2 beta-casein-A scientific perspective on health benefits. Journal of Conventional Knowledge of Holistic Health, 5.

Kamiński, S., Cieślińska, A., \& Kostyra, E. (2007). Polymorphism of bovine beta-casein and its potential effect on human health. Journal of Applied Genetics, 48, 189-198. https://doi.org/10.1007/BF03195213

Kaskous, S. (2020). A1-and A2-Milk and Their Effect on Human Health. Journal of Food Engineering and Technology, 9, 15-21. https://doi.org/10.32732/jfet.2020.9.1.15

Keating, A. F., Smith, T. J., Ross, R. P., \& Cairns, M. T. (2008). A note on the evaluation of a beta-casein variant in bovine breeds by allele-specific PCR and relevance to $\beta$-casomorphin. Irish Journal of Agricultural and Food Research, 99-104.

Kora, S. (2005). Milk and Cheese in Benin (Master's Thesis, Faculty of Agricultural Sciences, University of Abomey-Calavi, Benin). Retrieved from https://www.memoireonline.com/04/10/3418/m_lait-et-fromageau-Benin25.html

Kumar, S., Singh, R. V., \& Chauhan, A. (2019).: Molecular characterization of A1/A2 Beta-casein Alleles in Vrindavani crossbred and Sahiwal cattle Indian Journal of Animal Research, 53, 151-155. https://doi.org/10.18805/ijar.B-3493

Lin, B., Sun, J., \& Fraser, I. D. (2020). Single-tube genotyping for small insertion/deletion mutations: Simultaneous identification of wild type, mutant and heterozygous alleles. Biology Methods and Protocols, 5, bpaa007. https://doi.org/10.1093/biomethods/bpaa007

Malakootikhah, F., Naghavi, H., Firouzabadi, N., Maadani, M., Shafiei, M., \& Tajik, N. (2021). Association of human platelet alloantigens encoding gene polymorphisms with the risk of coronary artery disease in Iranian patients. BMC Cardiovascular Disorders, 21, 1-9. https://doi.org/10.1186/s12872-021-01892-z 
Massella, E., Piva, S., Giacometti, F., Liuzzo, G., Zambrini, A. V., \& Serraino, A. (2017). Evaluation of bovine beta casein polymorphism in two dairy farms located in northern Italy. Italian Journal of Food Safety, 6, 6904. https://doi.org/10.4081/ijfs.2017.6904

Miluchová, M., Gábor, M., \& Trakovická, A. (2014). Analysis of beta-casein gene (CSN2) polymorphism in different breeds of cattle. Scientific Papers Animal Science and Biotechnologies, 47, 56-59.

Nei, M., \& Li, W. H. (1979). Mathematical model for studying genetic variation in terms of restriction endonucleases. Proceedings of the National Academy of Sciences, 76, 5269-5273. https://doi.org/10.1073/ pnas.76.10.5269

Nei, M., \& Roychoudhury, A. K. (1974). Sampling variances of heterozygosity and genetic distance. Genetics, 76, 379-390. https://doi.org/10.1093/genetics/76.2.379

Ouédraogo, D., Soudré, A., Yougbaré, B., Ouédraogo-Koné, S., Zoma-Traoré, B., Khayatzadeh, N., ... Burger, P.A. (2021). Genetic Improvement of Local Cattle Breeds in West Africa: A Review of Breeding Programs. Sustainability, 13, 2125, 2021. https://doi.org/10.3390/su13042125

Parashar, A., \& Saini, R. K. (2015). A1 milk and its controversy-A review. International Journal of Bioassays, 4, 4611-4619.

Park, Y. W., \& Haenlein, G. F. (2021). A2 Bovine Milk and Caprine Milk as a Means of Remedy for Milk Protein Allergy. Dairy, 2, 191-201. https://doi.org/10.3390/dairy2020017

Priyadarshini, P., Mishra, C., Mishra, B., Swain, K., Rout, M., \& Mishra, S. P. (2018). Impact of milk protein on human health: A1 verses A2. Int J Chem Stud, 6, 531-535.

Rahimi, Z., Gholami, M., Rahimi, Z., \& Yari, K. (2015). Evaluation of beta-casein locus for detection of A1 and A2 alleles frequency using allele specific PCR in native cattle of Kermanshah. Iran Biharean Biologist, 9, 85-87.

Raynes, J. K., Day, L., Augustin, M. A., \& Carver, J. A. (2015). Structural differences between bovine A1 and A2 $\beta$-casein alter micelle self-assembly and influence molecular chaperone activity. Journal of Dairy Science, 98, 2172-2182. https://doi.org/10.3168/jds.2014-8800

Ristanić, M., Glavinić, U., Vejnović, B., Maletić, M., Kirovski, D., ... Stanimirović, Z. (2020). Beta-Casein Gene Polymorphism in Serbian Holstein-Friesian Cows and Its Relationship with Milk Production Traits. Acta Veterinaria-Beograd, 70, 497-510. https://doi.org/10.2478/acve-2020-0037

Saha, S., Amalfitano, N., Bittante, G., \& Gallo, L. (2020). Milk coagulation traits and cheese yields of purebred Holsteins and 4 generations of 3-breed rotational crossbred cows from Viking Red, Montbéliarde, and Holstein bulls. Journal of Dairy Science, 103, 3349-3362. https://doi.org/10.3168/jds.2019-17576

Şahin, Ö., Boztepe, S., \& Aytekin, İ. (2018). A1 and A2 bovine milk, the risk of beta-casomorphin-7 and its possible effects on human health: (I) A1 and A2 milk and the risk of beta-casomorphin-7. Selcuk Journal of Agriculture and Food Sciences, 32, 632-639. https://doi.org/10.15316/SJAFS.2018.146

Sebastiani, C., Arcangeli, C., Ciullo, M., Torricelli, M., Cinti, G., ... Biagetti, M. (2020). Frequencies Evaluation of $\beta$-Casein Gene Polymorphisms in Dairy Cows Reared in Central Italy. Animals, 10, 252. https://doi.org/10.3390/ani10020252

Soleimani, V. D., Baum, B. R., \& Johnson, D. A. (2003). Efficient validation of single nucleotide polymorphisms in plants by allele-specific PCR, with an example from barley. Plant Molecular Biology Reporter, 21, 281-288. https://doi.org/10.1007/BF02772803

Toko, R. C., Adegbidi, A., \& Lebailly, P. (2015). Valorisation des produits laitiers dans les ménages Peul du Nord-Est du Bénin. International Journal of Biological and Chemical Sciences, 9, 2716-2726. https://doi.org/10.4314/ijbcs.v9i6.16

Torell, R., Bruce, B., Kvasnicka, B., \& Conley, K. (2003). Methods of Determining Age of Cattle. Cattle Producer's Library-CL 712. Retrieved from http://avc-beef.org/AgingCattleGrifin/AgingCattle-CL712

Tougan, P. U., Daouda, I. H., Djenontin, J. A., Gouwakinnou, G., Adakamou, S. G. T., \& Mekpo, L. A. (2018). Aptitudes fromagères et beurrières, et qualité technologique du lait des vaches de races Borgou et Azawak élevées sur pâturage naturel au Bénin. Bulletin de la Recherche Agronomique du Benin, 41-50. 
Ugozzoli, L. A., Lowery, J. D., Carrera, P., Ferrari, M., Cardillo, E., \& Wallace, R. B. (1999). DNA probe-based assay for the detection of the Factor V Leiden (A16910G) mutation. Clinical Chemistry (pp. A42-A42). Amer Assoc Clinical Chemistry, Washington, DC.

Volkandari, S. D., Indriawati, I., \& Margawati, E. T. (2017). Genetic polymorphism of kappa-casein gene in Friesian Holstein: A basic selection of dairy cattle superiority Journal of Indonesian Tropical Animal Agriculture, 42, 213-219. https://doi.org/10.14710/jitaa.42.4.213-219

Willing, E.-M., Dreyer, C., \& Van Oosterhout, C. (2012). Estimates of genetic differentiation measured by FST do not necessarily require large sample sizes when using many SNP markers PLoS ONE, 7, e42649. https://doi.org/10.1371/journal.pone.0042649

\section{Abbreviations}

BCM-7: beta-casomorphin 7; DNA: Deoxyribonucleic Acid; PCR: Polymerase Chain Reaction.

\section{Copyrights}

Copyright for this article is retained by the author(s), with first publication rights granted to the journal.

This is an open-access article distributed under the terms and conditions of the Creative Commons Attribution license (http://creativecommons.org/licenses/by/4.0/). 